\title{
Right Laparoscopic Adrenalectomy in a Bitch
}

\author{
Fernando Wiecheteck de Souza', Cristiano Gomes ${ }^{2}$, Priscila Natasha Kasper ${ }^{3}$, Marília Teresa de Oliveira ${ }^{4}$, \\ João Pedro ScusselFeranti ${ }^{4}$, Peterson TrichesDornbusch ${ }^{5}$, Rafael Ricardo Huppes ${ }^{6}$, Lucas Lubasinski Daniel ${ }^{5}$, \\ Maurício Veloso Brun 7 , Arícia Gomes Sprada ${ }^{8}$ \& Josiane Morais Pazzini ${ }^{8}$
}

\begin{abstract}
Background: The medical procedure of Laparoscopic adrenalectomy is common in human medicine; however, this is not true in veterinary medicine, where it isperformed rarely. The current treatment of choice for adrenal neoplasms is total adrenalectomy, unless there is a pre-operativediagnosis of metastasis that precludes surgery. The laparoscopic approach option becomes an interesting alternative because, through this technique, it has shown good results. In this report, we demonstrate the experience of a case in which we performed unilateral laparoscopic right adrenalectomy, without caudal vena cava invasion, in a dogsuffering from hyperadrenocorticism caused by adrenocortical carcinoma.

Case: A 9-year-old beagle bitch, $12 \mathrm{~kg}$ in weight, showedpolyphagia, polydipsia, polyuria, pendular abdomen, thin and dark skin, lumbar alopecic areas and lethargy. The team carried out Complete Blood Count (CBC), blood chemistry (liver and renal functions) and urine sampling by cystocentesis for urinalysis and bacterial culture. All exams had normal results, except for ALP, which reached levels higher than $150 \mathrm{UIL}^{-1}$. On abdominal radiographic examination, we noted mild adrenal enlargement, and by ultrasonography, it was possible to identify adrenal asymmetry and right adrenal enlargement $(2.8 \times 2 \times 2.15 \mathrm{~cm})$ in relation to the left gland $(2 \times 1 \times 1.5 \mathrm{~cm})$. As a treatment for adrenal neoplasm-dependent HAC, we recommended the execution of total right adrenalectomy execution. The videosurgery used four accesses arranged in the right hypogastric region; the diameters were 10 (two), 5 , and $3 \mathrm{~mm}$. The adrenal gland was carefully dissected with the aid of laparoscopic forceps; during the intraoperative period, there was a small laceration of the abdominal phrenic vein that resulted in bleeding, which was overcome with two titanium clips. The dog had an excellent recovery, and the team discharged it $48 \mathrm{~h}$ after the procedure. The signs of hyperadrenocorticism disappeared about two weeks after surgery. One year after having the procedure, the animal remainswell and has no signs of tumor recurrence or Cushing's syndrome.

Discussion: The choice laparoscopic approach provided less invasiveness in surgical access, reduced animal convalescence, and provided image magnification for the more accurate dissection of the adrenal gland. Some reports that middle-aged to older bitches were the most predisposed to present adrenal neoplasm-dependent HAC, and generally, in unilateral form, characteristics which are presented in this report. Among the clinical signs and observed in this report, are polydipsia, polyphagia, tachypnea, alopecia, and skin hyperpigmentation. That recommended the low-dose dexamethasone suppression test to diagnose Cushing's syndrome and the endogenous ACTH test to distinguish hypophysary from adrenocorticotrophic HAC. The same tests were performed in the case reported here, as these are also important to establish the final diagnosisand refer the total adrenalectomy realization. In the current case report, access to the right hypogastric region using four videosurgery portals provided good surgical access. Towards the hospital convalescence time, the animal was discharged early, just $48 \mathrm{~h}$ post-operatively; remission of HAC clinical signs occurredwithin three weeks, and the survival already reached 12 months. To the best of the authors' knowledge, this is the first successful case of total right adrenalectomy without caudal vena cava invasion via the laparoscopic route as treatment for adrenocortical carcinoma in the national literature.
\end{abstract}

Keywords: adrenal gland, neoplasm, videosurgery, dogs. Federal de Santa Catarina (UFSC), Curitibanos, SC, Brazil. ${ }^{3}$ M.V. autônoma, Maceió, AL. ${ }^{4}$ Doutorado, Universidade Federal de Santa Maria (UFSM), Santa Maria, RS, Brazil. ${ }^{5}$ Departamento de Cirurgia Veterinária, Universidade Federal do Paraná (UFPR), Curitiba, PR, Brazil. ${ }^{6}$ Faculdade Unicesumar, Maringá, PR. ${ }^{7}$ Programa de Pós-graduação em Medicina Veterinária, UFSM, Santa Maria. ${ }^{8}$ Doutorado, Universidade Estadual Paulista - UNESP / FCAV Jaboticabal, SP, Brazil. CORRESPONDENCE: J. Pazzini [josipazzini@ hotmail.com - Tel.: +55 (16) 991515157]. Universidade Estadual Paulista - UNESP / FCAV. Via de acesso Rod. Paulo Donato Castellane, s/n. CEP 14.884-900 Jaboticabal, SP, Brazil. 


\section{INTRODUCTION}

The current treatment of choice for adrenal neoplasms is total adrenalectomy, unless there is a pre-operativediagnosis of metastasis that precludes surgery $[3,4,9]$.

The laparoscopic approach option becomes an interesting alternative because, through this technique, it has shown good results. Fewer surgical wound complications, lower morbidity, higher comfort and esthetic appeal, bleeding reduction, better abdominal organ observation, lesser hospitalization time, and faster recovery are some of the related advantages of the technique $[5,8,10]$.

Peláez et al. [8] performed seven unilateral laparoscopic adrenalectomies in dogs with adrenocortical carcinoma, three of them on the right side and four on the left, without caudal vena cava invasion, and using 4 access portals for all procedures. Two of these animals diedin the first $48 \mathrm{~h}$ after surgery, due to respiratory complications. Five of them were discharged $72 \mathrm{~h}$ post-operation, and showed remission of the clinical signs. There were no reports of trans-operatory major complications, and the paralumbar fossa allowed satisfactory surgical access. Survival of these animals varied between 7 and 24 months.

Due to the promissory results of right unilateral adrenalectomy by laparoscopy in dogs [8], we report our experience in a successful case of laparoscopic adrenalectomy realized through 4 abdominal access portals to treat a right adrenal adenocarcinomawithout caudal vena cava invasion in a bitch.

\section{CASE}

A 9-year-old beagle bitch, $12 \mathrm{~kg}$ in weight, showedpolyphagia, polydipsia, polyuria, pendular abdomen, thin and dark skin, lumbar alopecic areas and lethargy. The team carried out Complete Blood Count (CBC), blood chemistry (liver and renal functions) and urine sampling by cystocentesis for urinalysis and bacterial culture. All exams had normal results, except for ALP, which reached levels higher than $150 \mathrm{UIL}^{-1}$. Low-dose dexamethasone test (Decadron $\left.{ }^{\circledR}\right)^{1}\left[0.01 \mathrm{mg} \mathrm{kg}^{-1} \mathrm{IV}\right]$ wascarried out and showed cortisol concentrations higher than 1.5 $\mu \mathrm{g} \mathrm{dL}-1$, which were $50 \%$ lower than basal concentration, $4 \mathrm{~h}$ after dexamethasone application, and again after $8 \mathrm{~h}$ of application. The team also performed Endogenous ACTH dosing, obtaining values higher than $10 \mathrm{pgmL}^{-1}$. The first test, low-dose dexamethasone suppression, confirmed the HAC, and the second, endogenous ACTH, was important to distinguish whether the disease was hypophysisdependent or adrenal tumor-dependent, confirming the second condition. On abdominalradiographic examination, we noted mild adrenal enlargement, and byultrasonography, it was possible to identify adrenal asymmetry and right adrenal enlargement $(2.8 \times 2 \times 2.15 \mathrm{~cm})$ in relation to the left gland $(2 \times 1 \times 1.5$ $\mathrm{cm})$. As a treatment for adrenal neoplasm-dependent HAC, we recommended the execution of total right adrenalectomy execution.

The pre-anesthetic medication used in the patient consisted of $0.2 \%$ acepromazine $\left(\right.$ Acepram $^{\circledR}$ ) [0.05 $\left.\mathrm{mg} \mathrm{kg}^{-1}, \mathrm{IM}\right]$ and $50 \mathrm{mg} \mathrm{mL}^{-1}$ tramadol chlorhydrate $\left(\text { Tramal }^{\circledR}\right)^{3}\left[3 \mathrm{mgkg}^{-1}, \mathrm{IM}\right]$. As antimicrobial prophylaxis, $200 \mathrm{mgmL}^{-1}$ sodic ampicillin (Ampicilina $\left.^{\circledR}\right)^{4}\left[20 \mathrm{mgkg}^{-1}, \mathrm{IV}\right]$ was used. After $20 \mathrm{~min}$, we performed anesthetic induction with propofol (Diprivan $\left.^{\circledR}\right)^{5}$ [4 $\left.\mathrm{mgkg}^{-1} \mathrm{IV}\right]$, followed by orotracheal intubation using a $7.5 \mathrm{~mm}$ probe. The anesthetic maintenancewas $1 \%$ isofluranein (Isoflurine $\left.{ }^{\circledR}\right)^{6} 100 \%$ oxygen, which was carried by a universal vaporizer with a flow of $1 \mathrm{~L} \mathrm{~min}^{-1}$. The fluid therapycomprised a $10 \mathrm{~mL} \mathrm{~kg}^{-1} \mathrm{~h}^{-1}$ standard with $0.9 \% \mathrm{NaCl}$ saline solution.

Each animal was positioned in left lateral recumbence, to get access to the right adrenal region. After abdominal operatory field antisepsis, the surgeon made a paramedian incision of approximately $11 \mathrm{~mm}$ in the hypogastric regionusing an open technique, and a $10 \mathrm{~mm}$ portal was introduced into the abdominal cavity. Insulation of the abdominal cavity with medicinal $\mathrm{CO}_{2}\left(1.5 \mathrm{~L} \mathrm{~min}^{-1}\right)$ was done until 12 $\mathrm{mmHg}$ was reached. Then, with the $10 \mathrm{~mm}$ endoscope, direct visualization and $0^{\circ}, 2$ other portals were inserted, one of $5 \mathrm{~mm}$ (left hand) and another of $10 \mathrm{~mm}$ (right hand), in triangulation with the first one. After that, we inspected the abdominal cavity, and identified the enlarged right adrenal (Figura 1A), but it wasmisshapen. A fourth $3 \mathrm{~mm}$ portal was needed (just above the $5 \mathrm{~mm}$ portal) to move the kidney. Initially, we transected the hepatorenal ligament using a videolaparoscopyand metzembaum forceps to improve the operatory field. Then, the 
right adrenal was removed from the retroperitoneal space along with the adjacent vessels with the aid of mixter forceps and metzembaum scissors, all of them using videosurgery. In this step, a small laceration of the phrenicoabdominal vein occurred (Figura 1B), because of the adrenal enlargement due to the neoplasm. The hemorrhage was controlled through clipping of the vein using 2 medium titanium clips, and 2 other clips were positioned to occlude the 2 branches originatingfrom the renal artery. After complete liberation of the adrenal gland, we inserted a homemade retrieval bag, made of a surgical glove finger, into the peritoneal cavity through the right hand $10 \mathrm{~mm}$ portal and retrieved the gland along this portal. We performed manual morcellation using conventional Kelly forceps inside the retrieval bag to ensure the complete removal of the gland. The absence of hemorrhages was then confirmed, the cavity deflated and the access wounds were sutured using a sultan pattern and 2-0 910 polyglactin (Vicryl $\left.^{\circledR}\right)^{5}$ in the musculature. To provide closureof the surgical wound borders and dead-space reduction, another sultan pattern suturewasperformed using 3-0 910 polyglactin $\left(\text { Vicryl }^{\circledR}\right)^{5}$. The skin closure wasachievedusing 4-0 monofilament náilon $\left(\mathrm{Nylon}^{\circledR}\right)^{5}$ in a simple interrupted pattern. Histopathological analysis of the right adrenal gland (Figura 1C) confirmed the diagnosis of adrenocortical carcinoma. We recommended the administration of meloxicam $\left(\text { Meloxicam }{ }^{\circledR}\right)^{4}\left[0.2 \mathrm{mgkg}^{-1}\right.$, IM s.i.d.] and tramadol chlorhydrate $\left(\operatorname{Tramal}^{\circledR}\right)^{3}$ [3 $\mathrm{mg} \mathrm{kg}^{-1}$, SC, t.i.d.], for 3 and 5 days respectively, after anesthetic recovery. Then, $48 \mathrm{~h}$ after the end of the surgical procedure, the patient was discharged from hospital, and the

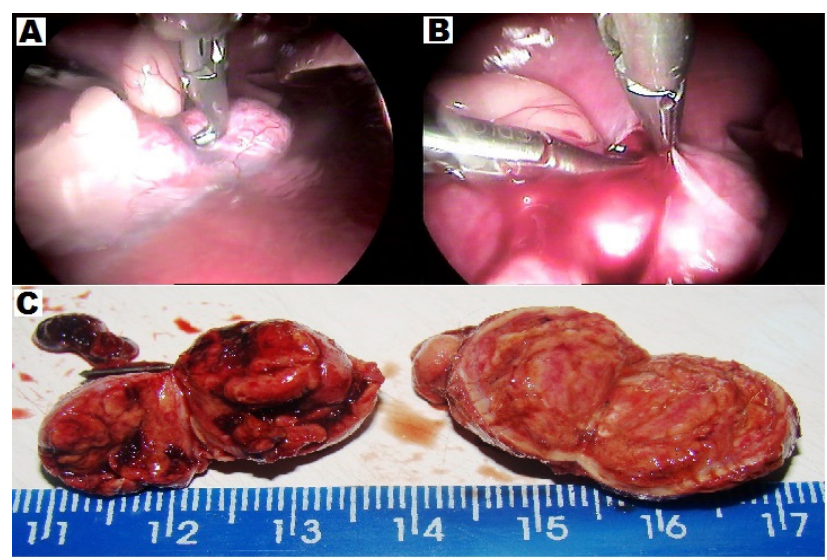

Figure 1. A- enlarged right adrenal located after inspection of the abdominal cavity. B- time oflaceration of the phrenicoabdominal. C- right adrenal gland removed by laparoscopy access.
HAC clinical signs disappeared about three weeks after surgery. A year after the surgical procedure, the animal did not present signs suggesting Cushing's syndrome or tumor reappearance at the adrenal gland extirpation site.

\section{DISCUSSION}

Birchard [2] reports that middle-aged to older bitches were the most predisposed to present adrenal neoplasm-dependent HAC, and generally, in unilateral form, characteristics which are presented in this report. Among the clinical signs cited by Reusch [11] and observed in this report, are polydipsia, polyphagia, tachypnea, alopecia, and skin hyperpigmentation.

Nelson [6] and Arenas et al. [1] recommended the low-dose dexamethasone suppression test to diagnose Cushing's syndrome and the endogenous ACTH test to distinguish hypophysary from adrenocorticotrophic HAC. The same tests were performed in the case reported here, as these are also important to establish the final diagnosisand refer the total adrenalectomy realization.

In the current case report, access to the right hypogastric region using four videosurgery portals provided good surgical access. Towards the hospital convalescence time, the animal was discharged early, just $48 \mathrm{~h}$ post-operatively; remission of HAC clinical signs occurredwithin three weeks, and the survival already reached 12 months. All of these data corroborate the observations of Peláez et al. [8] when in 2008, promoted the laparoscopic modality as a viable option for total right adrenalectomy.

To the best of the authors' knowledge, this is the first successful case of total right adrenalectomy without caudal vena cava invasionvia the laparoscopic route as treatment for adrenocortical carcinoma in the national literature.

\section{MANUFACTURERS}

${ }^{1}$ EMS Empresa Farmacêutica. São Bernado do Campo, SP, Brazil.

${ }^{2}$ Vetnil Ind. e Com. de Produtos Veterinários Ltda. Louveira, SP, Brazil.

${ }^{3}$ Cristália Produtos Químicos Farmacêuticos Ltda. Itapira, SP, Brazil.

${ }^{4}$ Medley Indústria Farmacêutica. Campinas, SP, Brazil. ${ }^{5}$ Ethicon $^{\mathrm{TM}}$ Johnson \& Johnson. São José dos Campos, SP, Brazil.

Declaration of interest. The authors report no conflicts of interest. The authors alone are responsible for the content and writing of the paper. 


\section{REFERENCES}

1 Arenas C., Pérez-alenza D. \& Melián C. 2013. Clinical features, outcome and prognostic factors in dogs diagnosed with non-cortisol-secreting adrenal tumors without adrenalectomy: 20 cases (1994-2009). Veterinary Record.173:501.

2 Birchard S.J. 2003. Adrenalectomy. In: Slatter D.H. (Ed). Small Animal Surgery. v.2. 3rd edn. Philadelphia: Saunders, pp.1694-1699.

3 Fossum T.W. \& Caplan E.R. 2013. Surgery of the Adrenal and Pituitary Glands. In: Fossum T.W. (Ed). Small Animal Surgery. 4th edn. St. Louis: Elsevier, pp.637-646.

4 Caplan R.H., Strutt P.J \& Wickus G.G. 2013. Subclinical hormone secretion by incidentally discovered adrenal masses. Archivos Surgery. 129: 291-296.

5 Lal G. \& Duh Q.Y. 2003. Laparoscopic Adrenalectomy - indications and technique. Surgery Oncology. 12: $105-123$.

6 Nelson R.W. 2010. Distúrbios da Glândula Adrenal. In: Nelson R.W. \& Couto C.G. (Eds). Medicina Interna de Pequenos Animais. 4.ed. Rio de Janeiro: Elsevier, pp.812-838.

7 Nichols R., Peterson M.E. \& Muller H.S. 1998. Glândulas Adrenais. In: Birchard S.S. \& Sherding R.G. (Eds). Manual Saunders: Clínica de Pequenos Animais. São Paulo: Roca, pp.270.

8 Peláez M.J., Bouvy B.M. \& Dupré G.P. 2008. Laparoscopic Adrenalectomy for Treatment of Unilateral Adrenocortical Carcinomas: Technique, Complications, and Results in Seven Dogs. Veterinary Surgery. 37: 444-453.

9 Reusch C.E. 2005. Hyperadrenocorticism. In: Ettinger S.J. \& Feldman E.C. (Eds). Veterinary Internal Medicine. 6th edn. v.2. St. Louis: Elsevier Saunders, pp.1592-1612.

10 Zografos G.N., Markou A. \& Ageli C. 2006. Laparoscopic surgery for adrenal tumors: A retrospective analysis. Hormones. 5: 52-56. 